\title{
THE IMPACT OF THE COMMONWEALTH GAMES 2010 ON URBAN DEVELOPMENT OF DELHI
}

\author{
Vinayak UPPAL \\ Centre for Civil Society, New Delhi, India \\ vinayakuppal@gmail.com
}

\begin{abstract}
India is all set to host the 2010 edition of the Commonwealth Games. This is the first major "hallmark event" to be hosted by New Delhi since the 1982 Asian Games. Hallmark events have the ability to transform the urban landscape of a city. This is the focus area of the paper. Can these games bring about a transformation of Delhi's urban landscape, and if it does, will it do so in an egalitarian fashion? It also looks at worldwide experiences from various other hallmark experiences like the Summer Olympics and the Asian Games, and Delhi's experience with hosting the 1982 Asian Games. What one finds is that these events are normally not as beneficial to the host community, as made out to be. More important in India's context is that the benefits are normally even less when the host community is a developing nation, as India is. The enormous expenditure on these is going to be spent largely on the development of civic infrastructure, beautification, transport and sports facilities. If spent effectively, the event can be a catalyst in a much-needed urban regeneration of the city. However past experience from the 1982 Asian Games and actions already undertaken in the run up to the 2010 games suggest that the development may be anti-poor, badly planned and ecologically unsound. It is essential that whatever actions are undertaken in the name of the Commonwealth Games, are well thought out and not justified solely on the grounds of nationalist sentiment and hyperbole.
\end{abstract}

Keywords: Commonwealth Games, Hallmark events, Delhi, Inequitable development, Developing Nations

\section{Introduction}

In 2010, one year from now, New Delhi will play host to the third largest multi-sporting event in the world, with tens of thousands of visitors descending upon the city. To prepare itself for this, the city is planning a major overhaul of its urban infrastructure as well as its sporting facilities. These events happen in a city once in a decade or maybe even less, (the last large event held in Delhi was the 1982) and have the ability to transform it.

Sports is now a very passionate and among many, an obsessive subject. In the run up to the Football World Cup 2006, the theme of football as a unifying religion has been played up numerous times in the media. Academicians even postulate that „religious pilgrimages of the past have been replaced by modern pilgrimages to such spectacles as the Olympic Games, the FIFA World Cup and other such events' (Gibson, 1998). Sporting events have now indeed become "spectacles", and with over 5 billion 
viewers expected, can give the host community a lot of exposure. India however still remains to make its mark on the world as a sporting nation. With the exception of cricket, and a handful of gifted individuals, Indians have performed quite miserably on the world stage. If one was to examine the last Olympics medal tally by population, that is, population divided by number of medals, India comes last by an enormous margin. Even after the 1982 Asian Games, which gave a dramatic boost to sports facilities in the country, our performance is yet to match international standards.

There are, therefore, some hard questions that need to be answered before one can conclude that such an event has a positive effect on the host community. Is the amount spent on such events worth it? One must remember that the funds that typically go into supporting these events are public funds and therefore should benefit society at large, or at least a large portion, and not just an elite minority. Some other questions that arise out of such events, with particular relevance in this paper, is its impact on the urban scene. Will the event lead to rampant and unchecked development, possibly unplanned? Will the infrastructure created be beneficial post-event or will it remain under utilised and fall into disrepair? Will the city's infrastructure be able to bear the strain of thousands of visitors that flood the city during such an event? Will the event prove to be a hindrance to the city's residents during the event? Will the event actually prove to be a boost to the domestic sports scene? There are numerous questions that arise from such events, many with inconclusive answers. However it is important for a prospective bidder of international sporting events, like New Delhi is, to carefully study all the pros and cons of such an event, and not fall into the trap of making it an issue of "national pride."

\section{Worldwide Experiences}

The world over, cities vie with each other to host "hallmark" events such as the Olympics, World Cup's etc. It is seen by many as a sure way of shooting the host city into the limelight, resulting in an "economic windfall" (Baade and Matheson, 2003), and at the same time giving these host cities the impetus to improve domestic facilities and infrastructure. The impact of being the host city, range from the physical (construction projects) to the intangible (local self-esteem or international impact). The impact that an event of this kind has on the urban landscape can largely be gauged by the size of the "legacy" that it creates. It is important to note here that it is not only legacy creation that is important, but creating a legacy which is beneficial to the host community post games, and which justifies the costs involved.

The controversy surrounding these events however is centred on its economic sense. Do these games make money for the host city or not? The data from past Olympic games seems to suggest not. All 
recent Summer Games with the sole exception of the 1984 Los Angeles Games have lost money. The citizens of Munich continue to pay a special tax to this day, to pay off debt incurred in the 1976 Games (Preuss, 1998). This is very often not revealed to the public by using smart accounting techniques that do not include a lot of the costs incurred under direct games expenditure. After the $\$ 200$ million profit that L.A. made on the games in '84, they have been increasingly looked upon as extremely profitable, though LA's performance is yet to be replicated (Baade and Matheson 2003). Interestingly only Los Angeles bid for the 1984 Games, largely due to the financial disasters that the Montreal and Moscow Olympic Games in 1976 and 1980 were. This fact explains the absence of significant public sector financial support in Los Angeles, and, perhaps, the private financial success the 1984 Games are thought to have enjoyed. Even here though employment effects and increased economic activity seem to have been transitory.

When numerous bidders are present however, theoretically the winning bid would be constant with a zero economic return on the investment if opportunity costs were included in the bidding calculus. The political nature of the event has however ensured that the games give a negative return. In other words government is willing to pay something for perceived political gains (Baade and Matheson, 2002). Today, the bid process has also become a very expensive and long drawn out affair. Some estimates place the amount spent by potential hosts for the 2012 Olympics during the bidding process at nearly 200 million euros.

In more recent years, therefore, hosting sporting events has been viewed as a prestigious achievement resulting in opportunities for economic profit, urban regeneration and global media exposure. Increasingly such sporting events are being aimed at increasing the exposure and visibility of the host city, and many academicians believe that success cannot be simply decided by profit and loss, as there are many intangible and unaccounted for benefits (Brown and Massey, 2001)

Urban regeneration and the re-imaging of cities is now a central aspect of game bids. Barcelona and Manchester can be viewed as partially successful in that they were able to re align the popular image of the city, both of which were manufacturing centres to that of tourist destinations as trendy European cities. In Delhi too, the emphasis is on portraying Delhi as a "world class" city, one of "international standards." This is of course a little more problematic in third world conditions as it requires a further marginilisation of the poor to portray this "image" to the world.

In Barcelona, for example, the largest component of investment went into the development of roads and transport facilities, while the construction of offices, commercial property, hotels and sports facilities also made up a large proportion. 


\section{Types of Projects}

The importance of the urban transformation of Barcelona due to the Games is seen in these proportions: in relation to the dimension in 1989, the new road projects meant an increase in expediture of $15 \%$, the new sewerage systems an increase of $17 \%$, new green zones and beaches an increase of $78 \%$, and ponds and fountains, an increase of $268 \%$. (Brunet, 1995).

Sporting events of these kinds are increasingly being seen as vehicles for urban renewal, a catalyst to create jobs, increase investment and transform the landscape of the city. The 2002 Commonwealth Games in Manchester were aimed primarily to "regenerate" the area which, had in recent years been undergoing a depression due to the re location of the many heavy engineering and chemical industries which had been the mainstay of the region's economy. The focal point of the regeneration was East Manchester which had been the worst affected. The Cambridge Policy Consultants estimate that the Games will help to regenerate approximately $60 \mathrm{ha}$ of land and create $72,000 \mathrm{~m}$ of employment floor space in East Manchester (Cambridge Policy Consultants, 2002). The image of the region seems to have been greatly improved by the games, with 18 million people visiting the region in 2002 putting $£ 6$ billion into the North West's economy, and with over 300,000 expected each year (Regeneration/Legacy. www.gameslegacy.com). The wish to host an event of this kind does not derive from a sense of philanthropy or love of sport, but is now largely seen as a business opportunity. The games act like a magnet, attracting attention, which in turn transforms into the more tangible investment and increased tourism.

Qatar, host of the 2006 Asian Games, has spent an estimated \$17 billion on the development of new sports, tourism and cultural facilities. ${ }^{1}$ The games were seen as an opportunity to launch Qatar as a major tourist and financial hub. Thus what one sees is that these hallmark events tend to serve as a "spotlight", focusing the world's attention on the host city. This often results in improved infrastructure for the cities' citizens, as well as increased interest in the city as an investment destination.

As seen by the table 1, sporting events have an impact on many facets of city's urban infrastructure. The table reflects the various sectors on which events like the Olympics, or the Commonwealth Games can have. The event does not only improve sports infrastructure, but over all infrastructure in the city. This is one of the themes than one sees recurring in a number of bids for the games. Cape Town in its failed 2004 Olympics bid highlighted the urban regeneration, and socio-economic impact that the event would have. The Cape Town 2004 Olympic bid was designed to be developmental, with every aspect of

\footnotetext{
${ }^{1}$ Advertisement in The Economist, May $27^{\text {th }}$-June $2^{\text {nd }}$ volume 379 number 8479
} 
the plan attempting to contribute to the "upliftment" of those previously disadvantaged under apartheid (Hiller, 1998)

TABLE 1 - IMPACT OF SPORTING EVENTSON CITY'S URBAN INFRASTRUCTURE

\begin{tabular}{|l|l|}
\hline \multicolumn{1}{|c|}{ Sector } & \multicolumn{1}{c|}{ Changes caused by the Olympics } \\
\hline Transportation & $\begin{array}{l}\text { The transportation system is changed by an improved infrastructure and new } \\
\text { concepts of public transportation. In Munich '72, the subway was expanded, in Seoul } \\
\text { 88 many major roads were improved and in Barcelona '92 the ring roads were built. }\end{array}$ \\
\hline $\begin{array}{l}\text { Telecommunication } \\
\text { system }\end{array}$ & $\begin{array}{l}\text { A high standard in telecommunications is another important location factor to keep } \\
\text { existing, or attract new enterprises. In this sector, the Olympics bring the latest } \\
\text { technology into the city to satisfy the demand in telecommunications services during } \\
\text { the Olympics. After the games, the systems remain existent. }\end{array}$ \\
\hline $\begin{array}{l}\text { Sports } \\
\text { structure }\end{array}$ & $\begin{array}{l}\text { Olympics have the strongest influence on the sports facilities structure in the city. } \\
\text { There must be adequate and sufficient sports and training facilities for all sports at } \\
\text { an international level. After the games, these facilities are often available for leisure } \\
\text { sports. }\end{array}$ \\
\hline Housing & $\begin{array}{l}\text { In most cities, Olympic villages are newly constructed. The question of the social } \\
\text { distribution of the newly created housing units is reviewed. In Munich '72, the } \\
\text { Olympic Village was constructed for the socially deprived groups of society. In other } \\
\text { cities, the Olympic Villages were sold to the middle and lower-upper classes. In Los } \\
\text { Angeles '84 and Atlanta '96, the villages continued to be students' homes. }\end{array}$ \\
\hline Urban culture & $\begin{array}{l}\text { The general embellishment of a city, an improved transportation system, additional } \\
\text { leisure time facilities and numerous ecological projects frequently lead to a revival of } \\
\text { the city centre by improving the "city atmosphere." }\end{array}$ \\
\hline
\end{tabular}
Source: Preuss, 1998

The costs of these mega-events almost always run in to billions of dollars. Japan spent over $\$ 4$ billion, and South Korea $\$ 2$ billion, on new stadiums and infrastructure for the 2002 World Cup. China has spent a reported $\$ 20$ billion on infrastructure improvements ahead for 2008 Olympics. Athens spent over $\$ 1$ billion only on security expenses during the 2004 Olympics (Baade, R and Matheson, V, 2003). Substantial economic impact provides backers of such events with a justification for public subsidies for mega-event infrastructure. They argue that the expenditure must be viewed as an investment that will in turn give returns. However this is a case where vested interests are at stake. Many independent researchers have found that ex ante predictions made by the event organizers of economic impact, far exceed the ex post estimates. The obvious question that results from this, is the cost justified, is yet to be answered conclusively either way.

This brings us to another interesting development, the arrival of developing nations on the sportshosting scene. Developing nations have only hosted two summer Olympics, one Winter Olympics, one Commonwealth Games and six football World Cups. This of course, due to the changing world order and rising prominence, is set to change. Beijing has host the 2008 Summer Olympics, India, the 2010 Commonwealth Games, South Africa the 2010 Football World Cup and South Asia the 2011 Cricket World Cup. However research seems to point out that though the benefits of hosting these events are 
dubious at best, the factors seem to work expressly against developing nations. The experience that a developing nation faces is vastly different from that of a developed nation. This is especially pertinent in the Indian context as we prepare to host the 2010 Commonwealth Games, and make a push to host the 2014 Asian Games, and the 2016 Olympic Games.

As Matheson and Baade (2003) point out, there are very good reasons for why developing nations are more adversely impacted by such events. They can be listed as:

1. High infrastructure development costs.

2. Under utilization of facilities post event

3. High opportunity cost of capital

4. Unable to attract large numbers of spectators

The first factor that works against developing nations is the lack of existing infrastructure. In order to host the 1994 World Cup, the United States spent less than $\$ 30$ million on sports infrastructure improvements, compared to over $\$ 2$ billion spent by South Korea for the 2002 World Cup. For the 1982 Asian Games in New Delhi, only one pre- existing stadium was used, while all the rest were new.

The development of professional sporting leagues with dedicated followings in developed nations means that post event; the facilities can be utilized efficiently. The expenditure on these facilities is exceedingly large, and for them to be good public investments, efficient post event usage is crucial. In developing nations these facilities are beneficial as they provide world-class facilities for athletes in that country. However it is also seen that in such nations, facilities tend to be grossly underutilized. Bureaucracy and the lack of a developed sports economy means that these "world-class" are not only inefficiently used post- event but also tend to fall into disrepair. One need not look far for an example, all over one sees sports infrastructure developed for the 1982 Asian Games lying derelict and unused. After the 2002 football World Cup, teams from the Japanese football league, J-League, moved into the new stadiums while South Korea on the other hand had few plans for the new stadia.

Nigeria' government recently spent $\$ 330$ million on a new national soccer stadium, more than the annual national government expenditures on health or education. In developing nations the opportunity cost of developing sports infrastructure is very high, as the money can be used for more pressing needs. Even though Japan spent an estimated $\$ 6$ billion in the run up to the World Cup, there was little criticism as the economy was suffering a recession and the government had committed itself to high public expenditure, making the opportunity cost of capital practically zero.

Developed nations may also be able to attract a larger number of spectators compared to developing nations where residents may be unwilling to pay the high ticket costs or where a sporting culture is not 
highly developed. In the 2002 World Cup, Japanese stadiums were filled to $89.1 \%$ capacity for its 32 games while Korean stadiums achieved only a 78.8\% capacity, this even though the South Korean team did surprisingly well, boosting sales.

All the factors do not work against developing nations. Low wages, meaning lower operational costs, general infrastructure improvements and a low opportunity cost of labour all factors that work in their favour. However the evidence seems to suggest that the economic effects of such events, especially in the case of developing nations, is not always as positive as the event organizers would have us believe. This is something we need to keep in mind as India attempts to make a mark in the world-sporting map by hosting the 2010 Commonwealth Games, and makes a push for the 2014 Asian Games and the 2016 Olympics. We should well heed the advice given by the same authors.

Cities and countries would be well advised to more thoroughly evaluate booster promises of a financial windfall from hosting a sports me ga-event such as the World Cup and Olympics before committing substantial public resources to such an event. Indeed, hosting these premier events may be more of a burden than an honor.

\section{Asian Games 1982, New Delhi.}

1982 saw the return of the Asian Games to its original home, New Delhi. The first edition of the Asian Games had been held in 1951 with eleven participating nations and six competitive sports. By 1982, the games had grown manifold with 33 nations and nearly 4600 athletes and officials participating in 21 sports and 147 events, the largest ever Asian Games. ${ }^{2}$ The games had grown to be the second largest sporting event in the world, second only to the Summer Olympics.

The 1982 Games was the first time after independence that the country was playing host to an international event of this magnitude. The world's attention was about to be focused on the city and it was not going to disappoint. The games were an announcement to the world that India had arrived. The games seem to have a very deep felt impact on the country as a whole, interestingly in many arenas far removed from sport. My focus here will be its impact on urban development of Delhi, though I will touch on some of the other effects as well.

The 1982 Asiad almost didn't take place at all. Though India had won the bid to host the games in 1976, by 1980 no work had even started and the Games surely looked doomed. There had been a change of government in-between and a lot of political turmoil had plagued the country in those years. In 1980,

2History of the games. http://www.doha-2006.com/en/asian_games_2006/history.aspx.(accessed on 28-05-06) 
Indira Gandhi was back in power, and she along with her son Rajiv Gandhi, made it her personal mission to pull off a successful games. The city was to be prepared to host the largest event it had ever experienced, along with build numerous stadiums, flyovers, hotels and the Games Village in a span of 20 months. That the Asian Games Special Organising Committee (SOC) was able to pull it off is commendable, though there were numerous shortcomings as well. Buildings like the player's building and the roof of the Talkatora swimming pool weren't completed on time, development was haphazard and short sighted, and there was little importance given to planning norms and regulations. There is little information pertaining to the Asian Games available in the public domain, and the little that does remain is scattered among the tens of government organisations that dealt with the event. It is therefore also nearly impossible to get an accurate picture of the total expenditure on the games, though estimates seem to place it at between 7-10,000 million rupees, (Lin and Patnaik, 1982) a sum a nation as poor as India could hardly afford. At the same time, revenues were almost negligible. The SOC made about 60 million rupees through ticket sales, donations and franchising revenue, a sum not even enough to cover the operational costs of 150 million. ${ }^{3}$ Foreign tourists, who were supposed to enter the city in the thousands, never materialised. Only an estimated 200 arrived, leaving hotels and restaurants empty. ${ }^{4}$

Economics and planning were often put aside as all trumpeted the notion of "international prestige". The Games had become an emotive issue, and anyone raising questions about it was unpatriotic and a traitor. One notices this in such events worldwide, where the backers of such events make it a nationalistic issue whereby it is unpatriotic to ask any questions, even when what is at stake is billions of dollars.

No queremos goles, queremos frijoles (we do not want goals, we want beans) was painted on a Mexico stadium during the Football World Cup in 1986 (Andreff, 2008). That statement in some way reflects the scenario in India in 1982 as well. The nation was still a heavily protected and closed economy, reeling under babudom and unable to shake off the "hindu" rate of growth.

"Hypocrisy and cynicism are even more evident than usual in New Delhi. The crores being spent on Asiad, The Asian Games of 1982, stand out in sharp relief against the real requirements of the people... The twisted values involved in advertising the luxuries and choice of expensive dishes available in five star hotels when millions are in search of food... descriptions of spacious air-conditioned suites each fitted with colour television sets. and other luxuries, appear side by side in the newspapers with grim

${ }^{3}$ Asiad report

4 1982. Turnout for Games Lags, New Delhi Paper Says. The New York Times. November 26. 
reports of near famine conditions in large parts of the country". (Indian Express, October 30, 1982) (Hall and Ritchie, 1999)

The famine conditions were not very far from the sight of the capital city itself. The construction spree that took place required workers, lakhs of them, with over 1.5 lakh workers working on sites directly related to the games, with many more on other construction projects. These workers were often paid lower than minimum wages, and forced to live in temporary jhuggies that a large majority never moved out of. Homeless people also reported that harassment increased, as there was a need to "clean up" the streets for the Asian Games, when the Bombay Prevention of Begging Act was used liberally to remove many hundreds of people forms the streets of Delhi (Speak, n.d.)

Any old timer in the city will tell you that it was in 1982 that Delhi finally began to "develop". The build up to the games saw an unprecedented construction spree in the city with stadiums, the games village, hotels, flyovers and roads, even Pragati Maidan being built, all with 1982 as the deadline. The skyline of the city literally changed overnight. Very few records remain on the public domain of the actual details of the construction that took place during that period, and few, if no, studies seem to have been conducted on the Games' impact.

The construction at the time can be broadly categorised into four groups:

1. Stadiums- The Jawaharlal Nehru Stadium was the centrepiece of the games, being the venue for the opening and closing ceremonies and athletics. The other major stadiums built at the time were the Talkatora Stadium, the Indira Gandhi Indoor stadium and the Yamuna Velodrome. One notices that with the exception of the National Stadium, which was an earlier construction, most of the venues for the 1982 Games were new constructions.

2. Asiad Village- The Games village, where all the participating athletes and officials were to stay was a large project developed in the Siri Fort area.

3. Hotels- A number of hotels came up at the time like the Kanishka, the Mughal Sheraton and The Taj Palace.

The unprecedented nature of the construction involved for the games meant that the Master Plan, a broad outline for the planned development of the city, was largely sidelined in the name of "national prestige" (Baviskar, 2005). Normal planning procedures for land use changes and development were largely sidelined and nationalistic fervour meant they often won in the face of opposition from critics. The other aspect which meant that planning was often put on the back seat was the fact that the entire infrastructure for the games were largely built in the last 2 years leading up to the games, and not the 46 years that a country normally takes to prepare itself for an event of this size (Sisodia, 2005). Internal 
unrest and infighting had meant that the development of infrastructure had been left right to the last minute.

Though thousands of crores were spent at the time to develop world-class stadiums, the construction undertaken for the games was largely of a shoddy and poor quality, reflecting the haste in which they were built. The Player's building was never completed, nor was the roof of the Talkatora swimming pool. The retracting roof of the Indira Gandhi indoor stadium hailed as a technological feat never worked effectively and even after numerous repairs, the roof still leaks. An international Badminton competition in the 1990's was disrupted due to water leaking in. The main stadium, built on the banks of the Yamuna is actually tilting on one side. The Delhi High Court also sealed the main portion of the stadium, as it does not fulfil fire safety norms (Venugopal, 2005). The adjoining Yamuna Velodrome is in a pathetic state with the velodrome full of cracks and bumps, and more often visited by snakes and rats than humans. The Nehru Stadium too is crumbling and bad maintenance means that even though new tracks were laid recently, they are already in disrepair. Utilisation of these stadiums has also not been very high. Bad maintenance has meant that they cannot be used for high profile international events and even domestic events are not held very often. The stadiums do serve as training grounds for the Sports Authority of India (SAI) but the fact remains that these stadiums have not been used to capacity since 1982. The stadiums are used more often for Bollywood events or political rallies than sporting events. Recently the only high profile international event that the famed J.N. Stadium has been used for is the Half Marathon where it was the starting and end point! There are therefore some hard questions that must be answered about the "legacy" that such events create. Numerous stadiums were built in "82 but not a single one has been maintained appropriately and therefore none of them has been used effectively. It is quite apparent that these stadiums are simply given a facelift in the run up to an event but otherwise left in a state of disrepair. This also means that the domestic athletes training there do not have up to the mark facilities.

The core of the Asian games was the village that was developed by the DDA, in the Siri Fort area. The design of the Games village, by noted architect, Raj Rewal, was considered a great success and revolutionary in its "cluster" approach to housing (Rewal, 1985). The complex was taken over as government housing post-event, soon becoming a much-coveted address among government and PSU officials. The development of this site probably had the largest urban impact on the city due to its correlation with the development of south Delhi. South Delhi was a region that had already begun being developed, but it was only after the 1982 games that saw this region increase in importance. Three of the four flyovers developed at the time, the Moolchand, Sewa Nagar and Oberoi flyovers were in south Delhi. The city, which had been growing rapidly, was running out of space and this region seemed 
perfect for development. The area where the village was developed, Siri Fort, was originally a Master Plan green but at this time was reallocated for the use of the village. The reason that the games had such a deep impact on the development in south Delhi was because they provided the region with the necessary infrastructure to develop. It provided the region with broad roads and flyovers for swift movement of traffic and other infrastructure as well such as water, electricity and other civic amenities. The other large residential complex built at the time was the Player's Building, which was envisaged as a VIP complex meant for senior officials and visitors during the games. The Players' Building wasn't finished on time and remained uninhabited for 15 years, till it was reborn as the Delhi Secretariat.

The hotels built at the time were largely government owned and operated. The state of government hotels need not be enumerated here but it is widely accepted that they were mostly money losing ventures. These hotels hardly ever rose above occupancy rates of $40 \%$, mostly propped up by government and PSU conferences filling up rooms. The government hotels are mostly in a sorry state, though privatisation, like the new Shangri-La has saved some from complete ruin.

The broader roads and flyovers were welcome additions to the cities crumbling infrastructure at the time, easing congestion and quickening transit times. They were however biased in their location as they were all built with the purpose of serving the ' 82 games, meaning that they were not located in the most congested places which needed them most but on routes which the athletes would take between stadiums and the games village. The ring roads too were further broadened at the time, roads which are now the lifeline of the city. The four flyovers built at the time also led to tens more being built during the '80s and '90s drastically easing congestion even in the face of ever increasing numbers on the road. The ring road is today virtually stop less with almost all traffic lights on the route being eliminated through flyovers.

The effect of an event of this magnitude on the environment can be quite detrimental, increasing pollution and causing imbalances by rampant, unchecked development. Unfortunately little research seems to have been undertaken at the time. One can point out however that certain areas, which were originally planned to be green open areas for the city, were developed at the time. Also further portions of the Ridge area, a no build zone, were encroached upon. The duration of the games also saw a rise in the lead concentration in the air, probably due to the rise in automobiles on the roads at the time (Boralkar, Mukharjee, and Singh, 1986).

One implication of an event like this taking place in the city, especially pertinent in the Indian context is the fact that it sets a deadline for projects. In the words of a senior DDA official, all the projects like roads, flyovers and hotels would have taken place even without the games, it's just that they would have 
taken 10 years instead of the 2 that they did. This comment is very true in the Indian context where construction often takes years and years with no end in sight. The games were able to fix a date before which the project must be completed which ensured that construction did not slacken. This is even more apparent when seen in the context of the introduction of colour television. In the build up to the games there was a decision taken to broadcast the games in colour. This gave DD the impetus to almost overnight upgrade their existing technology to support this, an up gradation that might have otherwise taken years.

The Asian Games was in some senses a landmark event in the country with far reaching implications. The games had an impact on areas as diverse as the Khalistan movement to the judicial process in the country to television broadcasting. Some of the interesting impacts are enumerated below.

By 1982, the Khalistan movement was already well under way. In an attempt to highlight their condition, protest marches were scheduled in Delhi during the games. In an attempt to counter this, the government took a tough stand, rounding up Sikhs all over the country and in the capital. No Sikhs were allowed to proceed towards Delhi and all means of transport were monitored. Bhajan Lal, the Chief Minister of Haryana took an exceptionally strong stand, not allowing the movement of Sikhs in the state. Many Sikhs, even those with reason to travel to Delhi were roughed up, further embittering them.

S. Khushwant Singh, speaking in the Parliament on the President's Address, warned that the country would have to pay a heavy price for the treatment meted out to Sikhs during the Asiad. He warned the government, "Was it ever realised that in so doing the government embittered thousands of Sikhs and played into the hands of Akali extremists by confirming their charge of governmental discrimination against the Sikhs? If, God forbid, the Khalistan movement catches on, it will owe much to the foolish short-sightedness of Bhajan Lal"5. Thus in some ways, the Asiad can be seen as a major factor in the rise of anti- government sentiment among the Sikhs.

In the construction frenzy that preceded the Asian Games, lakhs of workers entered the city, increasing the population of the city from 55 lakh to 65 lakh (approx., Source-Dunnu Roy) in a span of a few years. These workers were forced to stay in cheap temporary housing, which most of them never moved out of, and receive below minimum wage pay. In a landmark case, the Asiad worker's case (Peoples' Union for Democratic Rights Vs. Union of India, AIR 1982 SC 1473), filed by the People's Union for Democratic Rights (PUDR), the Supreme Court allowed what has now become known as Public Interest Litigation (PIL). (Subramaniam, 1999) Thus one of the first PIL's, a tool often used by concerned

${ }_{5}^{5}$ Dharam Yudh Morcha http://www.sikhpoint.com/religion/sihhistory/MainEvents/dharamyudhmorcha.htm 
citizens now, was filed on behalf of the Asiad workers. This case was seminal in the context of the minimum wages act as it held a person receiving less than minimum wage, a bonded labourer. The court ruled, "Where a person provides labour or service to another for remuneration which is less than minimum wage, the labour or service provided by him clearly falls within the scope and ambit of the word 'forced labour"..." All labour rewarded with less than the minimum wage, then, constitutes forced labour and violates the Constitution of India (Sreenath, Sreenath, and Student Group, 2005). The Supreme Court held that a person who provides service to another for less than the minimum wage renders forced service, i.e. "begar" within the meaning of Article 23 of the constitution. This ruling was very important in the workers fight against exploitation, and ensured that non-payment of minimum wages would be considered a serious offence and viewed as a violation of the Constitution of India.

One of the most visible effects of the Asian Games was the advent of colour television. To promote the games, the government directed DD to air the games in colour, and also allowed the import of colour TVs, a big policy change in those protectionist days. The Asian Games also led to the setting up of the Department of Sport, now the Ministry of Youth Affairs and Sports, and the National Informatics Centre (NIC) the body responsible for providing network backbone and e-Governance support to Central Government, State Governments, UT Administrations, Districts and other Government bodies (Sisodia, 2005).

\section{Commonwealth Games 2010, New Delhi}

"See You in Delhi", was the message that the Indian contingent had for the world, during the closing ceremony of the 2006 Melbourne Commonwealth Games. In 2010, India is going to become the second developing nation ever, to host the Commonwealth Games (CWG), the third largest multi sport event in the world. New Delhi, which has earlier played host to the 1982 Asian Games, is preparing itself to amaze the world. The games have the ability to transform the city's urban landscape and at the same time may simply be an extremely expensive "PR" exercise. Considering the Indian contingent spent Rs. 40 crores on getting the message, "See You in Delhi", across at the closing ceremony of the Melbourne games in an 11-minute show, it might end up being just that. The challenge is to ensure that the potential of the games as a catalyst for change is harnessed.

The CWG is going to be the first mega-event hosted by the city since the 1982 Asian Games, a gap of nearly thirty years. Much has changed, and yet much has remained unchanged in this time. India is preparing to break out on the world scene as an economic superpower, and the games are a step in propelling India on to the world stage. Yet India is still a poor country, ranked 127 out of 177 in the 
Human Development Index $(\mathrm{HDI})^{6}$, and therefore one must question the rationale of spending more than a billion dollars on a sporting event. Is it going to be simply an exercise in nationalism and politician supported patriotism or is it going to have some notable positive effects on the community, and if so what precisely?

Since 2003, when India won the bid to host the games, various agencies and government bodies have been hard at work making plans for the upcoming event. The over arching theme seems to be to make Delhi a "world class" city by 2010. This of course is a task easier said than done in a city of nearly 15 million people, growing at a phenomenal pace, and largely in a haphazard manner. Urban renewal or regeneration has been a theme in many such events in the past and appears an important one in the 2010 games as well.

This is because it gives an opportunity to improve the infrastructure and appearance of the host city, and also gives global media exposure meaning that the image of a city can be transformed in the eyes of viewers. This was certainly true of Barcelona, which successfully rid itself of its traditional manufacturing city image when hosting the 1992 Olympics (Brown and Massey, 2001). Manchester used the 2002 Commonwealth games as a tool to revive East Manchester, formerly an industrial area that had been suffering low growth and degradation? ${ }^{7}$. The urban landscape Delhi too, is set to change dramatically with many infrastructure projects being pushed through in time for 2010 .

In Delhi's bid for the games, it states that through the games, the city wishes to, among other things:

1. Stimulate economic growth and development.

2. Improve city infrastructure. 8

Thus two of the professed aims of the games are to improve the welfare of the citizens of the city through improving facilities and promoting investment in the city. The focus area of the games this time is going to be East Delhi, across the yamuna, where the games village and some of the venues are to be located. Residents of the area are hoping for a similar transformation as the one South Delhi experienced in the run up to the 1982 games. Infrastructure investments have already increased dramatically in the region with a new bridge being built at Wazirabad, the metro phase 2 being constructed, and numerous flyovers and roads in the pipeline. There are indeed ambitious plans afloat ranging from improving street furniture to setting up more power stations before the 2010 deadline.

The work ahead of the games can be broadly grouped into the following:

\footnotetext{
6UNDP Press Release No. 300, http://www.undp.org.in/NEWS/PRESS/2005/PRESS300.HTM

${ }^{7}$ www.gameslegacy.com

8 The Report of the Commonwealth Games Evaluation Commission for the 2010 Commonwealth Games.
} 
1. New Stadiums and renovation of existing stadiums

2. Games Village.

3. Transport sector.

4. Urban infrastructure like water and electricity.

5. Efforts to make Delhi "world-class".

Originally the plan was to build a completely new athletics stadium, one that would outrival J.N. Stadium. However lack of funds and available land has meant that the organising team has had to rein in its ambitions. Now the plan is to build one large new stadium, an aquatics centre in the Delhi University with five swimming pools, as well as a new TT hall in the Yamuna Sports Complex and new stadiums for Badminton and Squash in the Siri Fort Sports Complex. The project in DU, which is going to give a major boost to sports there, is to have an Olympic-size (50 metres) pool, a diving pool, pool for synchronised swimming, one for water polo and a warm-up pool as well as a gym. The university is also set to be the venue for the Rugby 7's event.The existing stadiums are however going to need extensive renovation before they can match up to the standards of the CWG. As reported in the Indian Express, the work remaining on the existing stadia is extensive. The estimated expenditure, only for renovation work, is over Rs. 1250 Crores. (Ramachandran, 2006).

Though construction of new stadiums and up gradation of the existing ones is central to the run up to the Games, the CWG is after all a sporting event; it is by no means the only focus area. Delhi is attempting to give itself a major facelift due to the games, and develop a whole portion of the city, East Delhi and the Yamuna riverfront, which until now has been largely neglected. As Delhi expands rapidly and space runs out, the until now undeveloped Yamuna riverfront, largely inhabited by slum dwellers and vegetable growers, is looking like prime real estate. The banks of the Yamuna are the largest open space left in the city, as well as the largest groundwater recharge zone. The $25 \mathrm{~km}$ stretch along the river has $97 \mathrm{sq} \mathrm{km}$ of prime land, 7 per cent of Delhi's total area (Sethi, 2005). DDA and other government authorities seem to have big plans for the area, developing the banks as green spaces and commercial areas. The proposals are centered on a "Thames-type Plan", channeling the river and reclaiming the land for other uses. A first step in the development of the region is the Games Village, a mammoth Rs. 955 crore project being built on a 63.5-hectare site by the DDA, for the 8000 plus athletes and officials expected for the event. The land has already been acquired from UP at a cost of Rs. 19 Crore and the project is in the planning stage (Vishnoi, 2006). The village will of course not be a one off structure, but will need extensive transport links, amenity providers and so on. There are also eight to nine hotels planned for the area, which will in turn give rise to other auxiliary services coming up. The village will be a well-planned site, with facilities for recreation, commercial activities, hospitals, training, 
shopping and living, all at hand. Interestingly, one proposal for post event usage is to hand over the village to the Delhi University as hostels, as DU is facing a tremendous shortage of hostel space. ${ }^{9}$ This however seems to have run into rough weather with high costs involved and the DDA now seeming to prefer selling the units as mid income housing post games ${ }^{10}$. Housing too is to get a shotin the arm with over 40,000 low-income housing units to be built before the 2010 games ${ }^{11}$.

All this means rampant development of an area that is ecologically fragile and not suited for urban development. Already large structures like the Akshardham Temple, the power plants and the Delhi Secretariat encroach on the riverbed. It is thought to be unadvisable to construct on the riverbed as the area is low-lying and has sandy alluvial soil. Also the region is the city's largest groundwater recharge zone and rampant construction in the area would hamper this considerably. An integral part of the longterm plan for the river area is the channeling of the Yamuna. Many environmentalists however see this as a recipe for disaster. As Amita Baviskar points out "the Yamuna is neither the Thames nor the Seine. Its distinctive rhythm is harmonised to the Indian subcontinent's seasons. With the bulk of its flow concentrated in the monsoons, the Yamuna is liable to breach its embankments if denied its present fertile expanse." (Baviskar, 2005) Recent events in New Orleans point to the dangers involved with constructing levees and embankments to build on low-lying areas.

In a move to ready the area for development, "illegal" structures in the area are being demolished. This means that the slums that have spread in the area have to go, regardless of the fact that low-income housing is practically non-existent in the city and the slum dwellers are getting no relocation. The numbers can only be said to be frightening, in the last three years as many as 300,000 people have been evicted across New Delhi on top of the 280,000 who are being chased away from Yamuna banks ${ }^{12}$. Many people point out the obvious elitism in these moves, with structures like the Delhi Metro Depot, I.T. Park, near Shastri Park and the Akshardham Temple having to face no such problems, all sites which began construction before the Delhi government issued a 'Public Notice for Change of Land Use". (Sethi, 2005) Others like Dunnu Roy also point out that the reason for which these slums are ostensibly being removed, polluting the river, is illogical as these slums do not even receive enough water to be polluting the river.

The hospitality sector is another area that is estimated to grow rapidly in the coming years, with the help of the Commonwealth Games. The games are estimated to result in a large increase in demand for

\footnotetext{
${ }^{9}$ CWG evaluation report

10 Panel Discussion on Planning for Commonwealth Games. http://mail.architexturez.net/+/MPISG-Media/archive/msg01030.shtml

11 40,000 new houses before 2010 Games Source: The Hindu, Feb 22, 2006.

12 Slums, Shops Make Way for "World-Class" Delhi May 1st, 2006 http://www.sawf.org/newedit/edit05012006/places.asp
} 
hotel rooms, with one estimate putting the requirement at 30,000 rooms for 2010. DDA is planning on auctioning over 20 sites for hotels, many in the vicinity of the games village. This would not only add about 7500 rooms, but also raise hundred's of crores for DDA. As of now there are only 6,500 rooms available in the star category hotels and about 7,000 rooms in the budget category. Surrounding states are also preparing to cash in with UP planning on having over 5000 rooms ready before 2010.

The transport sector has recently been getting a lot of attention in the last few years as the Delhi government has made it one of their aims to develop an effective mass transport system in the city, and solve the massive congestion problem that the city faces. This emphasis is only set to increase with the games arriving soon. The plans are enormous; flyovers, bypasses, broader roads, a larger metro system, an integrated Rail Bus Transport system, a High Capacity Bus system, an electric trolley bus system and a Light Rail Transit system are all in the pipeline. (Roy, 2006) The transport sector has already been assigned the lion's share of the Tenth Plan outlay, at $23.68 \%$ of Rs. 23000 Crore $^{13}$.

The transport infrastructure planned to be in place before 2010 is enormous. 25 new flyovers and underpasses are being planned at an estimated cost of Rs. 1650 Crores. These flyovers are to be largely concentrated in East and South Delhi, as well as on the ring roads so to make them signal-free. An underground tunnel road is also in the pipeline, connecting the J.N. stadium with the Games Village. A new bridge over the Yamuna, at wazirabad, is almost in the construction stage, with the plans for the Rs. 464 Crores project ready. The bridge is at the centre of the regeneration plans that the city government has for the Yamuna area. It is to be the city's first hanging bridge and ready in time for the 2010 Games.

The roads of the city are to get a major facelift before the games with many bypasses and broadening projects planned. Roads like the Mehrauli-Mahipalpur Road, Mehrauli-Badarpur Road and interconnecting roads which link up to the airport are to be broadened. Along with this, roads, which interlink the various stadia, and around major tourist attractions are also to be improved at a cost of nearly Rs. 170 Crores. Two bypasses are also planned at a cost of around Rs 30 Crores (Roy, 2006). Another ambitious project is to develop a third ring road, which will actually encircle Delhi state. This "peripheral expressway" is projected to be $270 \mathrm{~km}$ long, with a 136-km Western Peripheral Expressway and a 134-km Eastern Peripheral Expressway, and will go through large parts of Haryana, UP and Delhi. This will dramatically reduce pressure on Delhi's existing ring roads, as at the moment inter-state traffic has no way of bypassing the city. This project, which was floated nearly a decade ago, has got a new lease of life with the 2010 Games around the corner, and construction is under way(Joshi,

\footnotetext{
${ }^{13}$ Plan Outlays http://delhiplanning.nic.in/Economic\%20Survey/Ecosur2003-04/CH7.pdf
} 
2005a).The maintenance of the two ring roads has also, for the first time, been handed over to private companies.

The emphasis of the present Rapid Transport system is now on the Metro. The metro, whose presentation before the Commonwealth Games evaluation team made a sizable impression, is at the core of developing an efficient mass transport system in the city with Phase 1 of the metro being fully operational. However more importantly, phase 2, aimed at extending the network much further in the city, is already under construction, and is set to be ready before 2010. This phase is going to require massive investment, over Rs 8000 Crores. (Chatterjee, 2006) The second phase is going to provide a vital transport link to East Delhi, with a dedicated Games Village station. (See map) The metro, which is already beginning to have an impact on the city's congested roads, will be able to make a much larger impact as its network and reach grows. The second phase, originally planned to be ready by 2010-2011 is now going to be operational by 2009 , due to the 2010 Games. The new line may even extend up to the airport in time for the Games. Other transport sector improvements slated for 2010 are $98 \mathrm{~km}$ of High Capacity Bus system, 32 km of electric trolley bus system, a Light Rail Transit system, 1,000 quality Radio taxis at airports and major railway stations, 200 new AC buses and 100 mini-buses for athletes, managers and officers and 800 deluxe buses for park-and-ride services for spectators. There are also plans afoot to set up three smaller ISBT's in the city. One of the most important improvements is to be the newly privatized airport. This point is enumerated on further, later in the paper.

The impact that the Games has on providing basic amenities to the city is crucial to how the city's citizens will view the games. It may not be the size of the stadiums or the number of flyovers that are built which will decide whether the games find a place in Delhi'ites hearts; it may be relatively less glamorous things like water, electricity, sanitation and solid waste management. In recent years Delhi has been reeling under a severe water and power shortage, and if the Games are able to expedite movement in these sectors, the citizens of Delhi will be the gainers.

The summer of 2006 saw one of the worst shortages of power in recent history with the government even attempting to clamp down on usage by homes, shops and commercial establishments. The peak power consumption this summer was 3725 MW; during the Commonwealth Games in 2010, consumption is estimated to be over $7000 \mathrm{MW}$, nearly double of this year's peak.(Joshi, 2005b) The government has already got two large new power plants in the pipeline, slated to be ready in time for the Games. However even with these in place, total production of power in Delhi will only reach a maximum capacity of $2300 \mathrm{MW}$, leaving a shortfall of at least $4700 \mathrm{MW}$. The two new plants, one in Bawana and the other, an extra unit being added to the existing Pragati plant, are both Gas based, and 
will add 1000MW and $300 \mathrm{MW}$ respectively to Delhi's production capacity. The present production is dependant on four power plants, The Indraprastha power plant, the Raj Ghat power plant, the Gas Turbine plant and Pragati power plant. However with the exception of the Pragati plant, which is only four years old, none of the plants can produce anywhere close to capacity due to outdated and ill maintained equipment. This makes the city heavily dependent on the Northern Grid for power. The Northern Grid is however already over burdened, supplying electricity to numerous northern states including Uttar Pradesh, Uttaranchal, Haryana, Punjab and Rajasthan. This might lead to a situation of FHB (Family Hold Back) as Jug Suraiya humorously points out in his article "Bhago Dilli".

"So all the bijli available, little as it might be, will be diverted from unessential consumers such as hospitals, schools, workplaces and private homes and given to foreign visitors. And if all this diverted bijli proves insufficient, extra supplies can be obtained from neighbouring areas like Gujarat, Madhya Pradesh, Tamil Nadu and the Andaman and Nicobar Islands."(Suraiya, 2006)

This, though exaggerated, may be quite an accurate picture of the situation sans 2010. Delhi's "worldclass" city status will be at stake, and to achieve this, it may be necessary to take some radical steps. The Games will have a very direct impact on power consumption, and we must see whether we are willing to pay the price for hosting the games, with others spending some nights in the dark.

Water is another problem very fast taking on crisis proportions. The city has one of the highest per capita water supplies in the world, at over 220 liters per person, per day. Yet water shortages are a perennial problem due to lack of accountability and the fact that they lose about 50 percent of available water. (Yadav, 2006) There is talk of improving water distribution systems before the 2010 games, a much-needed development for the city's citizens. New pipes will be laid in the area of the village to ensure better distribution. Water supply at stadia will also be upgraded along with and a new water treatment plant at the Games village (to treat a million gallons of water per day. Sanitation and sewerage, is also to be upgraded, and a dedicated sewage treatment plant constructed at the village

Solid waste management is another area where work has already begun to prepare the city. Waste management has been privatized in 6 of the 12 MCD zones already and 4 of the remaining 6 will also be privatized shortly. This step should be able to provide better quality, and save MCD money in the process. 
The Delhi Government is also planning on making provisions for more toilets in public spaces. "Better quality public toilet facilities on all major roads, markets, public places will be provided by PWD, MCD \& NDMC on BOT basis before Commonwealth Games, 2010."14

A large newspaper in the city recently ran a much publicized campaign called, "From Walled City to World City." The city seems to have begun a concerted effort to achieve what is known in the media as "global standards." In this effort there are numerous steps being taken to transform the face of the city, from better street lighting, to sleeker bus shelters to upgrading the airport. This effort is resulting in over Rs. 100 Crore being spent on street furniture and landscaping alone.(Roy, 2006) This will give the city a much needed facelift in terms of utilities like bus shelters, dust bins, street lighting and park benches.

The other major boost to infrastructure is the airport privatisation. In 1982, a new International Departure and Arrival hall had been built. This time, after a stringent bidding process, the government formally privatized the entire airport, with the GMR group winning the bid. The airport is now set for an overdue modernization plan with capacity to treble, from 10 million to 35 million, by 2010. This is an essential step towards improving connectivity within India and with the rest of the world, and will also play a determining role in the number of tourists who finally come to Delhi for the 2010 Games.

The attempts to make Delhi a "world class" city however has a darker side as it also means that a large number of marginalized people are further marginalized as they do not fit into the larger scheme of things. Demolitions of slums in the Yamuna pushta area have become increasingly commonplace with the site for the Games Village being in the vicinity. Over six lakh hawkers may also face evacuation before the games (Afsal, 2005). Migrant labour, which entered the city in lakhs in 1982, will probably have to face similar deplorable conditions this time around too. They are needed for the ambitious construction projects envisaged but will have to be kept out of sight, as their conditions would not be in sync with that of a world-class city like Delhi. It is extremely important to ensure that these games do not simply give added benefits to those who are already privileged, but also attempt to aid the marginalised, not further worsen their position.

The infrastructure developments that the city needs, will mean investments of over a billion dollars, not including the amount being spent on projects like the metro, airport and peripheral expressway. This is more than three times the estimate that the IOA had made in its bid for the games, which was under 300 million dollars. Like any such event, there are a number of agencies involved, at last count over 45. There are however four primary organisations co coordinating the work; namely the Sports Authority of

14 HIGHLIGHTS OF DELHI'S BUDGET 2006 2006-07 http://delhiplanning.nic.in/Budget\%20Speech/2006-07/highlights.pdf 
India, the Delhi Development Authority, the Delhi Government and the Commonwealth Games Organising Committee.

The Delhi government has asked for Rs 1,314 crore for creating infrastructure, flyovers, new roads and to find a solution to Delhi's chaotic traffic. DDA has to build the athletes' village and the new stadiums at Siri Fort Sports complex and the Yamuna sports complex, and have asked for Rs. 983 crore. The Sports Authority of India has asked for the biggest chunk of Rs 1,700 crore to renovate all existing stadiums as they are in a bad shape and need an urgent makeover. SAI also needs to build a few more stadiums. The organising committee, which has asked for Rs.980 crores will be spending Rs 200 crore for conducting the games, Rs100 crore for the opening and closing ceremonies, Rs 100 crore for equipment, Rs 50 crore for the expenses at the games village, Rs 40 crore for the media center, Rs 45 lakh to be paid to each of the 71 countries as part of the training expenses ${ }^{15}$.

\section{Conclusion}

One can see that at least on paper; the city is all set to transform itself by the time it plays host to the Commonwealth Games. However it is also necessary to keep one thing in mind, and that is that Delhi is otherwise too a rapidly growing city, a dynamic economy and an integral part of India's growth engine. Delhi is estimated to have a population of approx. 192 lakh people by 2010, compared to 140 lakh in 2001, a growth of nearly $40 \%{ }^{16}$. This means that it would be wrong to place the causation of all infrastructure and urban development onto the Commonwealth Games. A large amount of it would probably have taken place anyway, the games just gives it a geographical bias and a deadline.

The world over there is a serious re-think taking place among city officials as well as academics about the way to go about these events. Do they do more harm than good is not a question that has been answered conclusively, as many of the benefits derived are intangible ones. However it has yet to be conclusively shown that these events are beneficial as well and it is crucial to examine each event independently, studying its unique characteristics, as well as examine previous events and try and learn from their mistakes.

Delhi's citizens have a right to know about the benefits that such events can have to the city, but need to be informed of the downsides as well. The present plan for the Commonwealth Games may be a recipe for an ecological and financial disaster, or they might finally put the city, and the country, on the world map. They may bring in a new era where electricity and water problems, perennial problems in

\footnotetext{
${ }^{15}$ Commonwealth Games bill shocks Aiyar Sunday May 28, 12:22 PM http://in.news.yahoo.com/060528/211/64lri.html.
} 
the city, are no longer an issue or they might increase the burden on an already overloaded system. Popular perception tells us that the Asian Games was an unmitigated success. Closer analysis tells us that it was not so simple. The Commonwealth Games, with some smart marketing, may just follow in those footsteps.

\section{BIBLIOGRAPHY}

Afsal, M. (2005 June 07). Over six lakh hawkers may face evacuation before the games. The Age.

Andreff, W. (2008). Sport in developing countries. Rivista di Diritto ed Economia Dello Sport vol IV, Fasc. 3, 2008

Baade, R., and Matheson, V. (2002). Bidding for the Olympics: Fool's Gold?. Transatlantic Sport: The Comparative Economics of North American and European Sports, London: Edward Elgar Publishing, pp. 127-151.

Baviskar, A. (2005 November 06). A lifelime ... under siege. The Hindu.

Boralkar, D. B., Mukharjee, U. and Singh, S. B. (1986). Increase of lead concentration in ambient air during the IX Asian games, New Delhi, 1982 as indicated by the plants. Indian Journal of Air Pollution Control 1986; 7(2): 65-7.

Brown, A., and Massey, J. (2001). Literature Review: The Impact of Major Sporting Events. http://www.uksport.gov.uk/images/uploaded/M2002_Baseline_2001.pdf

Brunet, F. (1995). An economic analysis of the Barcelona'92 Olympic Games: resources, financing and impact. Barcelona: Centre d'Estudis Olímpics UAB. [Consulted: 26/05/06] http://olympicstudies.uab.es/pdf/wp030_eng.pdf

Cambridge Policy Consultants. (2002). The Impact of the Manchester 2002 Commonwealth Games. Manchester: Manchester City Council, http://www.sportdevelopment.org.uk/manimpactcpc.pdf (accessed-29-05-06)

Chatterjee, M.B. (2006). JBIC completes project appraisal for funding Delhi metro Phase II. The Business Line, Jan 28

Gibson, H. J. (1998). Sport Tourism: A Critical Analysis of Research. Sport Management Review, 1998, $1,45-76$

Hall, M., and Ritchie, B.(1999). Mega-Events and Human Rights in PROCEEDINGS OF SPORT AND HUMAN RIGHTS CONFERENCE 102, 113 (Tracy Taylor ed., 1999)

Hiller, H. H. (1998). Assessing the Impact of Mega-Events: A Linkage Model. Current Issues in Tourism Vol. 1, No. 1, 1998

Joshi, S. (2005 Feb 07)a. Peripheral Expressways get a new lease of life. The Hindu.

Joshi, S. (2005 March 06)b. Govt. in the dark about power situation. The Hindu.

Lin, S. G., and Patnaik, N. (1982). Migrant Labour at Asiad '82 Construction Sites in New Delhi. Bulletin of Concerned Asian Scholars Vol. 14, 1982.

Preuss, H. (1998). Problemizing Arguments of the Opponents of Olympic Games. Unpublished paper.

Ramachandran, R. (2006 April 03). Stadiums in disrepair, but no one's worried. The Indian Express. 
Rewal, R. (1985). Asian Olympic Village, Delhi. In Large Housing Projects: Design, Technology, and Logistics. Margaret Bentley Sevcenko, (ed). Cambridge, Massachusetts: Aga Khan Program for Islamic Architecture.

Roy, S. (2006). See you in Delhi....No, not yet. The Indian Express, April 02.

Sethi, A. (2005). A site of contestation. Frontline. Volume 22 - Issue 15, Jul 16 - 29, 2005

Sisodia, M. K. S. (2005). India and the Asian Games: From Infancy to Maturity. Sport in Society Vol. 8 , No. 3, September 2005, pp. 404-413

Speak, S. E. (n.d.). The right to safety in the city. Homelessness and safety in the city: a developing countries perspective, http://www.ciudad-derechos.org/english/pdf/aai.pdf

Sreenath, L., Sreenath, M. R., and Student Group. (2005). Child Labour: Implications on Children and Recent Government Initiatives http://www.tapmi.org/paper/cl.pdf

Subramaniam, C.N. (1999). Democratic Rights And the Working Class. Revolutionary Democracy Vol. V, No. 2, September 1999

Venugopal, A. (2005 November 14). Safety stain on Games pride. The Telegraph.

Vishnoi, A. (2006 April 04). Signpost's up, village still on drawing board. The Indian Express. 